as well as the scientific leadership. The 'Pilot' must serve as a physical tool to demonstrate to visitors, farmers and unconvinced people. This phase (validation) must be accompanied by new theoretical statements also producing new research questions or hypotheses.

(4) Using the farmer's leadership: detecting and monitoring evolution of successful practical cases

Simultaneously, the leadership of local individual farmers and societies must be identified. They should be in the same line of the more scientific approach. 'Model real farm' processes must also be conceived for evaluating their dynamics in space and time. Constant feedback with these real farms is essential.

\title{
Livestock farming systems and conditions of sustainability in Cuba, the case of small ruminant production
}

\author{
Y. Alexandrine ${ }^{1}$, X. Xandé ${ }^{1}$, J. Arece-Garcia², M. Mahieu ${ }^{3}$, J. L. Diman ${ }^{1 \dagger}$ and G. Alexandre ${ }^{3}$ \\ ${ }^{1}$ ARECA, Association de Réflexions et d'Actions sur les Agricultures Caribéennes, Lot Beaujean La Jaille, Baie-Mahault, 97122, Guadeloupe, France; ${ }^{2}$ EEPF Estacion \\ Experimental de Pastos y Forrajes, Indio Hatuey, Matanzas, Cuba; INRA UR 143 UR Zootechniques, Domaine Duclos, Petit-Bourg, 97170 Guadeloupe, France
}

\section{Introduction}

Beginning at the end of the 1990 's, the Cuban agricultural sector implemented a sustainable animal production (SAP) program for developing new livestock farming systems to reach food security at the country level. The main statements of SAP (Funes-Monzote et al., 2009) are to reduce the environmental impact, to increase the use of local resources (food, feeds, herbs and genotypes) and to promote an integrated approach of the production system (mixed farming system, MFS). Thus, the Cuban experience could be shared with other tropical regions. Given the high efficiency of small ruminant (SR) production under the Caribbean conditions (Alexandre et al., 2010), it appears interesting to study the SR systems and assess the conditions of their sustainability. A study has been carried out in 2 regions of Cuba on SR systems of production and their integration to the natural environment.

\section{Materials and Methods}

Thirty-four farmers were questioned (more than 360 questions*modalities) upon the crops, the different flocks, husbandry practices for SR (reproductive, feeding and health management). The use of different plant species for human consumption, animal use (feeding and sanitary practices) or other function was determined. The importance of diseases and pathogens is also described. All the data allow determining indexes of biodiversity and some criteria of sustainability according to Cammaert and Palacios (2006). A functioning typology of the different SR systems was implemented as described by Alexandre (2008). The indexes of biodiversity (species and diseases) and the criteria of sustainability were assessed at the sub-group level.

\section{Results and discussion}

The different groups of SR breeders were discriminated according to their main economic activity at the farm level and/or the area exploited by the animals (Table 1). The first group (A, 12\%) was made up of farmers where crop production is preponderant (pasture surfaces ranging

Table 1 Main description of the SR systems in Cuba, type of plant species exploited and indexes of biodiversity and sustainability

\begin{tabular}{|c|c|c|c|c|c|c|c|c|}
\hline Type & $\begin{array}{l}\text { Species: total } \\
\text { number }\end{array}$ & $\begin{array}{l}\text { Food: } \% \\
\text { of total }\end{array}$ & $\begin{array}{l}\text { Feeds: } \% \\
\text { of total }\end{array}$ & $\begin{array}{l}\text { Food/feeds: } \\
\quad \% \text { of } \\
\text { food + feeds }\end{array}$ & $\begin{array}{l}\text { Vegetables } \\
\text { and roots: } \\
\% \text { of food }\end{array}$ & $\begin{array}{l}\text { Forages: } \\
\% \text { of feeds }\end{array}$ & Diseases + parasites & $\begin{array}{l}\text { Index of biodiversity } \\
\text { and sustainability }\end{array}$ \\
\hline Crop farmers & 29.5 & 73 & 55 & 22 & 34 & 25 & 4.1 & 2.06 \\
\hline \multicolumn{9}{|l|}{ Livestock farmers } \\
\hline Pig & 21.6 & 63 & 61 & 19 & 28 & 31 & 3.2 & 2.13 \\
\hline Cattle & 21.8 & 50 & 61 & 9 & 2 & 29 & 4.2 & 2.15 \\
\hline \multicolumn{9}{|l|}{ SR breeders } \\
\hline Small unit & 21.9 & 66 & 58 & 19 & 18 & 31 & 4.3 & 2.26 \\
\hline Large unit & 20.0 & 49 & 64 & 12 & 8 & 39 & 5.0 & 2.16 \\
\hline Public areas & 21.8 & 51 & 65 & 14 & 20 & 36 & 4.8 & 2.40 \\
\hline
\end{tabular}

Diseases + parasites (number of pathogens); Index of biodiversity and sustainability adapted from Cammaert and (2006) score from $1=$ good to $3=$ very bad.

\footnotetext{
†E-mail: diman@antilles.inra.fr
} 
from 0.5 to 2 ha). The second group (B, 34\%) was defined as livestock farmers raising either pigs in a very integrated MFS, with use of byproducts from crops or cattle raising (combined or not with the SR and optimizing the use of natural resources). The $3^{\text {rd }}$ group (C, $54 \%$ ) was composed of SR breeders (as the main activity), divided according to grazing pasture area: the small unit using less than $15 \mathrm{ha}$; the large unit using more that $40 \mathrm{ha}$ and the ones using the public natural areas (67 to $402 \mathrm{ha}$ ). The proportion of species cultivated as food are higher in A than in C: 73 vs. $55 \%$. While the proportion of feeds that are forage species are 30,36 and $42 \%$, respectively. The different links between activities (crop and livestock) are explained in relation to the farm conditions but also according to the natural environment. The index of sustainability appeared to be better for the groups exploiting crops as in the A group or the MFS "pig" ones (with the use of by-products for feeding animals and herbs for health control).

\title{
Conclusion
}

In the fields of SR production, improving the reproductive performances of the SR, increasing the use of silvopastoral resources, and organising the milk and meat sectors are recommended. The importance of MFS for the future, the interest of local resources and non conventional practices of feeding and health control of the animals are highlighted for reaching sustainable production. This Cuban experience of SAP in the case of SR production could be shared with other farmers of the Caribbean.

\section{References}

Alexandre G, González-García E, Lallo CHO, Ortega-Jimenez E, Pariacote F, Archimède H, Mandonnet N and Mahieu M 2010. Goat management and systems of production: Global framework and study cases in the Caribbean. Small Rumin Res 89, 193-206.

Alexandre G, Leimbacher F, Maurice O, Domarin D, Naves M and Mandonnet N 2008 Trop Ani Health Prod 41, 635-644.

Cammaert C and Palacios MT 2006. Mi finca diversidad herramienta didáctica para la planificación de la biodiversidad en finca. Instituto Alexander von Humboldt. Bogotá, Colombia, 80 p.

Funes-Monzote FR, Tittonell P and Santiago-Lopez R 2009. Diversidad y eficiencia: elementos clave de una agricultura ecológicamente intensiva. Leisa abril 2009, p 12-15.

\section{Small ruminant feeding systems in semi-arid land of Punjab, Pakistan: status and prospectus for improvement}

\author{
Tanveer Ahmad ${ }^{1,2+}$, Nemat Ullah' ${ }^{2}$, Kashif Ishaq ${ }^{1}$, S. Anum Hadi ${ }^{1}$ and M. M. Fahd Qadir ${ }^{1}$ \\ ${ }^{1}$ Department of Livestock Production and Management; ${ }^{2}$ Department of Clinical Studies, Faculty of Veterinary and Animal Sciences, PMAS-Arid Agriculture \\ University, 46300, Rawalpindi, Pakistan
}

\section{Introduction}

Small ruminants (SR) are an integral part of mixed-farming systems in Pakistan. More than 85 million heads of both goats and sheep (GOP, 2009) belonging to 62 different breeds are available in the country (Hasnain, 1985). The majority of the SR flock owners are either landless or have a small piece of land ( $<5$ acres). In Pakistan, a mix of different feeding and management systems are in practice in different areas. The scarce information available on the production systems indicate that despite the different problems, the sustainable SR production is contributing a lot to the well being of small farmers. The aim of the study was to characterize and evaluate the existing feeding systems to determine the status and thus to identify areas for future developments.

\section{Material and methods}

The present study was conducted in the adjoining villages of Rawalpindi and Islamabad (commonly called twin cities), in the Punjab province of Pakistan. The twin cities are located (Latitude $33^{\circ} \mathrm{N}$ and Longitude $73^{\circ} \mathrm{E}$ ) in the Potohar Plateau in the northwest of the country. The mean monthly (Jan-09 to Dec-09) minimum and maximum temperature varies between $2.6-24.3^{\circ} \mathrm{C}$ and $17.7-38.7^{\circ} \mathrm{C}$, respectively (PMD, 2010). The monthly mean total rainfall varies between $17.8-309.9 \mathrm{~mm}$ (PMD, 2010). Small ruminant farmers $(n=50$, flock size $>5$ animals) having a history of keeping flocks for more than 18 months were randomly chosen and interviewed from each village that falls in the specified radius of $50 \mathrm{Km}$. A maximum number of farmers from each village were interviewed to gather detailed information. However, the famers having common feeding and management systems and residing in a same village were pooled to make a single unit. The data of only $\leqslant 5$ farmers from each village were used for statistical analysis. A structured questionnaire was used to collect information to assess the demographic factors, production parameters, feeds and feeding systems. The T-test was used to compare the live weight difference among kids and lambs.

\footnotetext{
† E-mail: tanvirah@yahoo.com
} 